\title{
VISÕES DE
}

PATRIMÔNIO E CIDADE:

\author{
INVENTÁRIOS DE BENS CULTURAIS NA \\ ÁREA CENTRAL DE SANTO ANDRÉ, REGIÃO \\ METROPOLITANA DE SÃO PAULO
}

\author{
ANDRÉA DE OLIVEIRA TOURINHO, UNIVERSIDADE SÃO JUDAS TADEU, SÃO \\ PAULO, SÃO PAULO, BRASIL \\ Arquiteta e urbanista pela Faculdade de Arquitetura e Urbanismo da Universidade \\ Presbiteriana Mackenzie. Mestre pela Universidad Autónoma de Madrid (Espanha). \\ Doutora pela Faculdade de Arquitetura e Urbanismo da Universidade de São Paulo. \\ Docente do curso de Graduação e do Programa de Pós-Graduação em Arquitetura e \\ Urbanismo da Universidade São Judas Tadeu. \\ E-mail: prof.atourinho@usjt.br. \\ ORCID: https://orcid.org/0000-0002-9167-9762
}

LARISSA TESUBAKE DE FARIAS, UNIVERSIDADE SÃO JUDAS TADEU, SÃO PAULO, SÃO PAULO, BRASIL

Arquiteta e urbanista pela Universidade São Judas Tadeu. Mestranda no Programa de PósGraduação stricto sensu em Arquitetura e Urbanismo da Universidade São Judas Tadeu, com apoio da Coordenação de Aperfeiçoamento de Pessoal de Nível Superior (CAPES) E-mail: larissa.tesubake@gmail.com

DOI 


\section{VISÕES DE PATRIMÔNIO E CIDADE: INVENTÁRIOS DE BENS CULTURAIS NA ÁREA CENTRAL DE SANTO ANDRÉ, REGIÃO METROPOLITANA DE SÃO PAULO ANDRÉA DE OLIVEIRA TOURINHO, LARISSA TESUBAKE DE FARIAS}

\section{RESUMO}

Este artigo analisa três inventários de bens culturais realizados no município de Santo André, no Grande ABC Paulista, região metropolitana de São Paulo, entre os anos de 1998 e 2009, com recorte espacial na área central da cidade. Os trabalhos foram realizados por distintas equipes: duas contratadas pela prefeitura e uma terceira integrante do corpo técnico da municipalidade. A análise comparativa desses inventários reflete diferentes visões de patrimônio e de cidade. Do conceito de "bem isolado" à "paisagem cultural", o caso de Santo André evidencia uma mudança conceitual acelerada no tempo, acompanhada de uma visão urbana em que a cidade da história cede lugar à cidade da memória.

PALAVRAS-CHAVE

Patrimônio cultural. Inventário de bens culturais. Urbanização. 


\section{VIEWS ON HERITAGE AND CITY: INVENTORIES OF CULTURAL PROPERTIES IN THE CENTRAL AREA OF SANTO ANDRÉ, METROPOLITAN REGION OF SÃO PAULO \\ ANDRÉA DE OLIVEIRA TOURINHO, LARISSA TESUBAKE DE FARIAS}

\section{ABSTRACT}

This article analyzes three inventories of cultural properties conducted in the municipality of Santo André, situated in the Great ABC Paulista, Metropolitan Region of São Paulo, between 1998 and 2009, with spatial clipping in the central area of the municipality, and was carried out by different teams, two hired by the City Hall and a third one part of the technical staff of the municipality. The comparative analysis of these inventories reflects different views on heritage and municipality. By utilizing the concept of isolated asset to cultural heritage, the case of Santo André shows a quick conceptual change followed by an urban view wherein the historic city gives way to the city of memory.

KEYWORDS

Cultural heritage. Inventory. Urbanization. 


\section{INTRODUÇÃO}

O patrimônio cultural, como campo de atribuição de valores, não é estanque, revelando múltiplas dimensões conforme a sociedade se transforma e traduzindo essas mudanças nas significações e nas visões que lhe são atribuídas. Para identificação e reconhecimento desses valores e dos bens culturais que lhe dão suporte foram desenvolvidos instrumentos como o inventário, que, desde o início das modernas práticas de preservação, no final do século XVIII, reúne as informações fundamentais para a escolha de bens a serem preservados. O inventário pode ser ainda adotado como um instrumento direto de preservação, como ocorre em alguns países europeus, que conferem proteção imediata aos bens inventariados, sem a necessidade de aplicação de outro instrumento - o tombamento, por exemplo -, tal como se verifica no Brasil.

O inventário revela, assim, os valores atribuídos aos bens culturais, que estão intrinsecamente relacionados a uma ideia de patrimônio então subjacente. Considerando a importância desse instrumento, este artigo analisa três inventários elaborados no período de uma década - entre 1998 e 2009 - no município de Santo André, situado no Grande ABC Paulista, na região metropolitana de São Paulo, tendo como recorte espacial o centro da cidade. 
Os dois primeiros inventários, de 1998 e de 2006, foram organizados pela Secretaria de Desenvolvimento Urbano do município de Santo André. Já o terceiro, de 2009, foi realizado pelo órgão municipal de preservação, o Conselho Municipal de Defesa do Patrimônio Histórico, Artístico, ArquitetônicoUrbanístico e Paisagístico de Santo André (Comdephaapasa), a saber:

(a) Inventário de bens culturais de interesse urbanístico, realizado em 1998, pelo arquiteto Décio Tozzi e equipe;

(b) Inventário do Plano de preservação do patrimônio histórico e cultural do município de Santo André, elaborado em 2006, pelo Laboratório de Urbanismo da Metrópole da Faculdade de Arquitetura e Urbanismo da Universidade de São Paulo (LUME/FAU-USP), sob a coordenação geral da arquiteta Regina Maria Prosperi Meyer; e (c) Inventário de bens culturais de Santo André, elaborado pelos técnicos do Comdephaapasa, em 2009.

Este trabalho emergiu justamente do interesse de se analisar comparativamente inventários elaborados em um espaço de tempo relativamente curto, por três diferentes equipes, com o objetivo de verificar as distintas visões de patrimônio e de cidade que, a partir de conceitos e valores culturais, cada inventário revela. $\mathrm{O}$ caso concreto, por tratar de inventários diferentes, mas de iniciativa do poder público municipal, possibilita a leitura da dimensão urbana do patrimônio cultural, em razão da estreita relação entre patrimônio e território, na escala da cidade.

Como será desenvolvido neste artigo, a análise comparativa dos três inventários mostrou que houve, no mencionado período, mudanças significativas na noção de patrimônio que resultaram na ampliação da concepção de bem isolado à paisagem cultural.

A pesquisa fundamentou-se em análise de fonte primária, tendo sido realizados levantamentos nos acervos do Museu de Santo André Dr. Octaviano Armando Gaiarsa e do Comdephaapasa. Procedeu-se à descrição dos inventários, ao mapeamento dos bens culturais neles indicados, às análises das fichas de identificação dos bens e ao exame das categorias de análise das equipes de inventariação, bem como dos valores culturais a eles atribuídos. 


\section{O MUNICÍPIO DE SANTO ANDRÉ: MARCOS DO DEBATE}

Santo André, com cerca de 718.773 habitantes (IBGE, 2019), foi considerada até recentemente uma importante cidade industrial, cujo processo de industrialização iniciou-se com a implantação, em 1867, da linha férrea pela companhia inglesa de trens São Paulo Railway e o consequente surgimento de um núcleo urbano ao seu redor. O processo de formação da cidade não proporcionou edificações de valores excepcionais ou atividades como o turismo, mas, sim, elementos que constituíram uma paisagem urbana própria.

O desenvolvimento do município ocorreu em dois períodos históricos distintos. O primeiro, entre os séculos XVI e XIX, caracterizou-se pela ocupação inicial do território que a cidade ocupa hoje, com a instalação da Vila de Santo André da Borda do Campo, fundada por João Ramalho, em 1553. Em 1560, essa vila foi desativada em consequência de diversos ataques de indígenas que, antes da formação da vila, ocupavam aquele lugar, transferindo-se as pessoas que ali viviam para a Vila de São Paulo de Piratininga.

Os poucos habitantes que ficaram nessa região tinham propriedades dedicadas à produção para sua subsistência. Como herança desse período, permaneceram os traçados dos antigos caminhos utilizados para a penetração no território, como o Caminho do Pilar, um importante eixo que interligava Mogi das Cruzes à estrada Caminho do Mar.

O segundo momento de desenvolvimento de Santo André ocorreu a partir do século XIX, depois de um longo período de ocupação esparsa do território, destacando-se, contudo, a existência, desde o século XVIII, de duas fazendas pertencentes à Ordem de São Bento: a Fazenda São Bernardo, que produzia alimentos, e a Fazenda São Caetano, onde eram produzidos tijolos e peças em cerâmica (KLEEB, 2002). A implantação da estrada de ferro que ligava Santos a Jundiaí intensificou a ocupação da região, formando um pequeno núcleo urbano, denominado "povoado da estação".

Em torno das estações ferroviárias, segundo Passarelli (2005), acontecia a vida urbana, pois ali se concentravam atividades como depósitos, armazéns, oficinas, bares e outras atividades antes encontradas próximas às capelas. A intensificação da ocupação nesse local proporcionou a abertura de mais caminhos ligados à ferrovia, bem como a reativação de outros caminhos existentes, como a Estrada de Mogi, que ligava o Caminho de 
Zanzalá ao Caminho do Mar, como uma alternativa mais rápida para o escoamento de produtos de Mogi das Cruzes (PASSARELLI, 2005).

$O$ período entre o final do século XIX e o início do século XX foi de grande importância para o então distrito de Santo André, com a instalação de diversas fábricas voltadas às indústrias têxtil, moveleira e metalúrgica, entre outras, como a Fábrica Ypiranguinha e a Fábrica de Cadeiras Streiff. Segundo Langenbuch (1971, p. 105):

\begin{abstract}
Muitos dos pequenos povoados das estações ferroviárias abrigariam também uma função industrial, compreendendo inicialmente o beneficiamento e a transformação de matérias-primas extrativas produzidas na redondeza. [...] Na estação São Bernardo (hoje Santo André) se instalara a indústria Streiff, que utilizando a mesma matéria-prima, já fabricava produtos mais elaborados, ou seja, móveis.
\end{abstract}

Dessa forma, a ferrovia impulsionou o desenvolvimento das atividades industriais em detrimento das atividades rurais anteriormente desenvolvidas na região. A população rural diminuiu consideravelmente nesse momento em razão da falta de incentivos para continuar com suas atividades e pelo fato de que as áreas antes agricultáveis, próximas ao núcleo urbano que se constituía, estavam bastante exploradas. Essas áreas, que já não eram produtivas, foram então parceladas por seus próprios proprietários sem nenhum tipo de planejamento, dificultando o acesso à energia, à água e a meios de transportes adequados a locais pouco utilizados e mais distantes, como afirma Kleeb (2013).

As indústrias instaladas na região tinham grande oferta de empregos e em suas proximidades foram construídas moradias, atendendo à demanda de habitação para os trabalhadores e suas famílias por meio de casas ou vilas operárias - como a Villa Ypiranguinha, projeto de 1909 (PASSARELLI, 2005) -, que propiciaram a abertura de novas vias.

Diante desse cenário, muitos habitantes de outras regiões migraram para o distrito de Santo André, que obtém sua autonomia como município em 1938. Entre 1944 e 1963, vários distritos de Santo André também alcançaram autonomia (PASSARELLI, 2005), vindo a constituir, assim, os sete municípios da atual Região do Grande ABC: Santo André, São Bernardo do Campo, São Caetano, Mauá, Diadema, Ribeirão Pires e Rio Grande da Serra.

No campo da cultura, na década de 1950, em Santo André, intensificaram-se diversas atividades, destacando-se aquelas organizadas pelos 
clubes das empresas - como o Clube Atlético da Rhodia, criado em 1953 -, que propiciavam aos seus frequentadores não apenas o convívio, mas o acesso a atividades culturais, como o teatro.

O Teatro de Alumínio, construído em 1962 no centro da cidade, também foi um importante ponto de encontro dos diferentes grupos da sociedade. Com o intuito de consolidar as atividades culturais no município, a prefeitura constituiu um conselho municipal para os assuntos culturais, além da formação de núcleos culturais, como a orquestra sinfônica da cidade. Em 1968, ano de demolição do Teatro de Alumínio, foi criado o Grupo de Teatro da Cidade, iniciando-se uma nova fase da cultura no município (TAKARA, 2018).

Segundo Kleeb (2013), o período entre as décadas de 1950 e 1980 foi de intensa transformação urbana na área próxima à estação de trem, tendo início um processo de verticalização na área central da cidade. Além de edifícios residenciais, foram também verticalizados edifícios públicos, como o Paço Municipal, construído em 1969. Entretanto, a necessidade de moradia não foi atendida, o que levou parte da população a buscar alternativas, como a ocupação de áreas periféricas, com o consequente surgimento de favelas.

Contribuíram também para a transformação da paisagem urbana o desenvolvimento da indústria automobilística e mecânica - atividades de grande importância para a economia da região, que demandavam a construção de rodovias para o transporte de seus produtos, como a Via Anchieta (1947-1953), uma das principais rodovias da Região do Grande ABC. Esse fato fez acentuar a lógica do desenvolvimento urbano ordenado pela mobilidade por meio do automóvel, construindo-se, assim, grandes vias e avenidas perimetrais, que cortavam o território, sendo pouco seguras para o uso de pedestres. Contudo, a falta de um planejamento integrado levou a um "descompasso entre a cidade real e a cidade planejada" (KLEEB, 2013, p. 47).

A partir de 1980, a Região do Grande ABC assiste a um processo de reestruturação produtiva, quando os sete municípios começam a passar por processos de desindustrialização. Muitas indústrias migraram para o interior paulista graças aos incentivos fiscais que eram oferecidos e aos terrenos com menores custos em comparação ao elevado preço do solo que se estabelecia em Santo André (ARMELINI, 2008). Nesse período, os movimentos sindicais tinham grande força junto dos operários das 
indústrias, que reivindicavam melhores condições de trabalho e salários. Diante desses fatores, diminuiu a oferta de empregos relacionados às atividades industriais na região, voltando-se então para o setor terciário, que cresceu expressivamente:

Dentre os negócios abertos com dinheiro das rescisões contratuais, estes variam desde pequenos restaurantes, minimercados, rotisseries, pequenas oficinas mecânicas e automotivas, serviços de distribuição de água mineral, pequenas lojas de roupas abertas em bairros periféricos, serviços de pedreiros, pintores, jardineiros, cozinheiros, entre outros (PINHO, 2007, p. 35).

Com essas novas condições, o direito à cidade começou a ser reivindicado por movimentos sociais a partir da década de 1980, quando também surgiu a preocupação com a preservação do patrimônio cultural. Episódios ocorridos na Região do Grande $\mathrm{ABC}$, como o incêndio na igreja da matriz, em Rio Grande da Serra, em 1980 - que seria tombada pelo Conselho de Defesa do Patrimônio Histórico, Arqueológico, Artístico e Turístico do Estado de São Paulo (Condephaat) -, e o incêndio da estação ferroviária na Vila de Paranapiacaba, em 1981, levaram a uma importante mobilização da sociedade civil em defesa da memória.

Em 1983 foi criada a Comissão Pró-Paranapiacaba, pela prefeitura municipal de Santo André, somando-se a outros movimentos que reivindicavam a preservação da vila, importante para o seu reconhecimento como patrimônio cultural. Em 1987, o Condephaat procedeu ao tombamento da Vila de Paranapiacaba, enquanto o Instituto do Patrimônio Histórico e Artístico Nacional (Iphan) o fez apenas em 2002, e quanto ao o município, em 2003. As questões do patrimônio histórico repercutiram em toda a Região do Grande ABC, com a realização de simpósios e congressos que reuniram representantes das sete cidades.

Também contribuiu para esse debate o jornal Diário do Grande $A B C$, importante veículo de informação da região que, em 1987, com a coordenação do jornalista Ademir Médici (1987), lançou a série "Inventários históricos", que consistia em publicações de cada uma das sete cidades do Grande $\mathrm{ABC}$, apresentando bens de interesse para preservação. Essa listagem foi resultante de pesquisas junto da população, nos jornais e nas prefeituras, indicando-se 27 bens de interesse para tombamento na região. 
O SOS Carlos Gomes foi outro movimento significativo, criado em 1987 pelo Grupo Independente de Pesquisadores da Memória do Grande ABC (GIPEM). O espaço do cineteatro Carlos Gomes foi um importante local de encontro de grupos sociais desde a década de 1920, em que ocorriam apresentações, festas, debates e que funcionou como local de cultura até 1987, quando ocorreu o seu fechamento. Sua fachada original foi modificada para receber uma loja, transformando-se, depois, em estacionamento (ARMELINI, 2008). Houve grande pressão popular, por meio de um abaixo-assinado, contra a demolição de parte da edificação, que foi desapropriada em 1990 e posteriormente declarada utilidade pública, sendo incorporada ao Circuito Cultural do Centro em 1991 (PASSARELLI, 2005).

Como resultado de movimentos a favor da preservação da cultura andreense e o contexto político favorável da gestão do prefeito Celso Daniel (1989-1992), o Comdephaapasa foi criado em 1990, iniciando-se as indicações para tombamento dois anos depois. Passados 30 anos e depois da realização dos três referidos inventários, que indicaram uma série de bens culturais com interesse de preservação, o município de Santo André atualmente conta com 24 bens tombados, sendo que apenas oito desses estão situados no perímetro de Zona Especial de Interesse do Patrimônio da Área Central (ZEIP, Figura 1), instituída no Plano Diretor do município de 2012.

FIGURA 1

Bens tombados dentro do perímetro da ZEIP Centro. Fonte: elaborado por Farias (2020) com base no Google Earth.

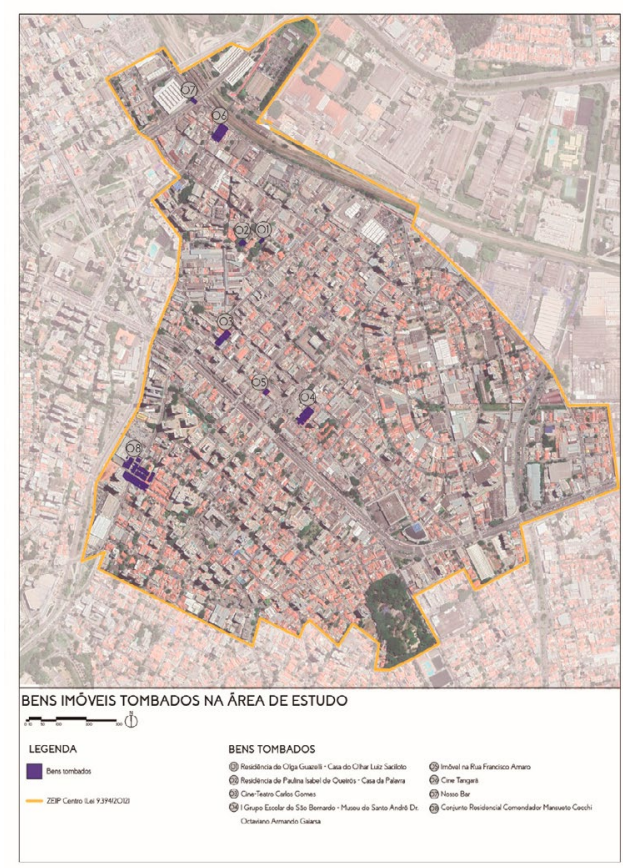


Além disso, considerando o significativo passado industrial da cidade, apenas o conjunto residencial Comendador Mansueto Cecchi remonta a essa memória, como uma vila de moradia voltada ao cidadão comum, distanciando-se do tombamento corrente de casas de personalidades ou de monumentos.

Feitas essas considerações, passaremos ao exame dos três inventários.

\section{IDENTIFICAÇÃO DO PATRIMÔNIO CULTURAL EM SANTO ANDRÉ: OS TRÊS INVENTÁRIOS}

\subsection{Inventário de bens culturais de interesse urbanístico, 1998}

Esse primeiro inventário foi realizado no âmbito do projeto municipal de reurbanização e revitalização da área central de Santo André, concebido no final da década de 1990 .

A partir de um cenário econômico de crise da indústria, a prefeitura, na gestão de Celso Daniel (1989-1992), desenvolveu o Projeto Centro com o intuito de alavancar a imagem da cidade, por meio de projetos de reurbanização e revitalização da área central. Contudo, esse projeto somente foi implementado em 1997, ficando conhecido como "Centro com Vida", que tinha como estratégia a

readequação da infraestrutura; reformulação do sistema viário; revisão geral da iluminação; tratamento urbanístico especial dos subcentros histórico, comercial e institucional; implementação de um corredor cultural; trabalho social com a população de rua; programa permanente de segurança pública; e a revisão da legislação de uso e ocupação do solo (GOLLO, 1997).

O projeto também tinha como proposta um circuito de visitação de bens culturais conhecido como "Corredor Cultural".

No âmbito desse projeto, o escritório coordenado pelo arquiteto Décio Tozzi ${ }^{1}$ foi contratado pela prefeitura para a elaboração de proposta para cobertura da Rua Coronel Oliveira Lima, que seria realizada em duas

1. Arquiteto titular do escritório Décio Tozzi Arquitetura e Urbanismo, foi professor na Faculdade de Arquitetura e Urbanismo da Universidade de São Paulo entre os anos de 1983 e 1994, além de ter exercido o cargo de diretor no Instituto de Arquitetos do Brasil de São Paulo em 1970 e 1971. 
fases, embora apenas a primeira tenha sido concluída, com uma extensão de 350 metros (TOZZI, 1998). Essa obra tinha como objetivo estimular o desenvolvimento das atividades comerciais, bem como tornar-se espaço de encontro da população (SALES, 1998).

Ainda nesse período, esse mesmo escritório também elaborou o primeiro inventário para o município, em 1998, com direção geral do referido arquiteto e coordenação técnica da arquiteta Nilza Maria Toledo Antenor, ficando conhecido como "Inventário de bens culturais de interesse urbanístico do centro principal e expandido do município de Santo André”, integrando o projeto de reurbanização e revitalização do centro principal e expandido do município de Santo André.

A criação desse primeiro inventário foi importante para fornecer elementos que visavam a elaboração de instrumentos urbanísticos que contribuíssem para as políticas públicas de uso e ocupação do solo na área central. Segundo a equipe do inventário, o objetivo era

servir de subsídio para a definição dos exemplares arquitetônicos de interesse histórico e cultural, que pelos elementos construtivos, representativos de fases do desenvolvimento da cidade, mereçam ser preservados por instrumento legal específico (TOZZI, 1998, p. 4).

Quanto aos valores atribuídos aos bens, a equipe privilegiou os valores estético-arquitetônicos e históricos,

\begin{abstract}
valores esses bastante abrangentes que constam tanto nas leis de tombamento, assim como pela sua autenticidade, a sua engenharia, a sua curiosidade e no seu conjunto de originalidade. Bens antigos ou modernos, bens que retratam uma época ou que são simplesmente agradáveis como obra estética e que por todos esses motivos passam a ser referência urbana (TOZZI, 1998, s/p.).
\end{abstract}

Como procedimento metodológico, foram levantados imóveis, monumentos e logradouros indicados em listagens da prefeitura, levantamentos bibliográficos e pesquisas em jornais e revistas. Também foi realizado levantamento iconográfico dos bens identificados consistentes em construções do século XX. A Figura 2 mostra a localização desses bens na área de estudo. 


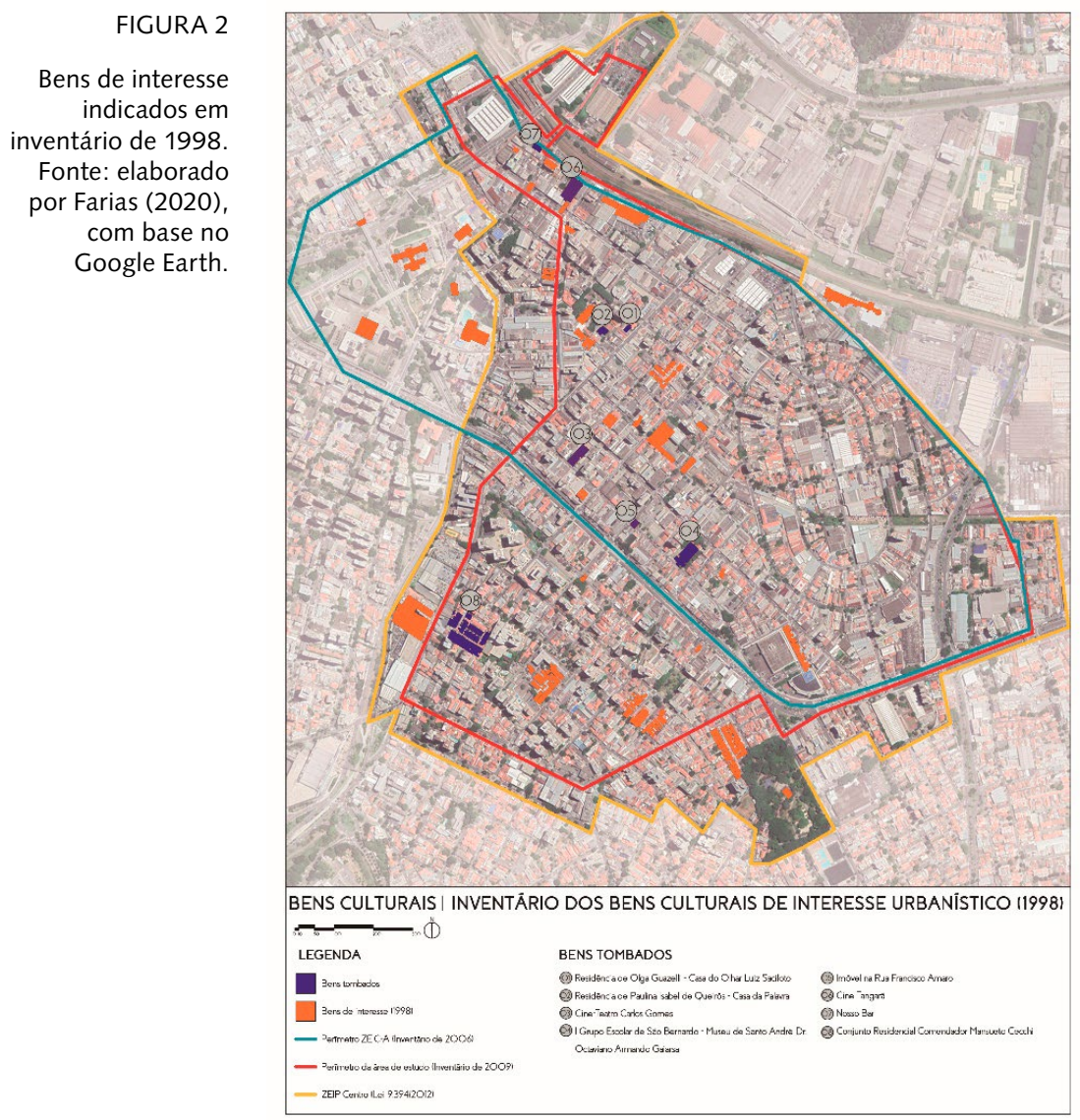

A classificação dos bens foi realizada com base na categoria analítica de tipologia: edifícios religiosos; conjuntos residenciais; edifícios residenciais; edifícios públicos; teatros, cinemas e clubes; edifícios escolares; edifícios industriais, comerciais e institucionais; logradouros; monumentos; e parques. A equipe sugeriu um roteiro de leitura do inventário a partir dos períodos históricos em que os bens foram construídos: 1. Primórdios - a cidade em formação; 2. O avanço da industrialização; 3. Modernidade.

A sistematização dos dados levantados foi apresentada em fichas (Figura 3), que contemplam categorias de identificação para os edifícios, como: nome; classificação fiscal; endereço; histórico, descrição, ambiência; número de pavimentos; uso original; uso atual; estado de conservação; e fotos antigas e atuais. As fichas de logradouros, monumentos e parques têm como identificação: endereço; histórico, descrição, ambiência; estado de conservação; e fotos antigas e atuais. 


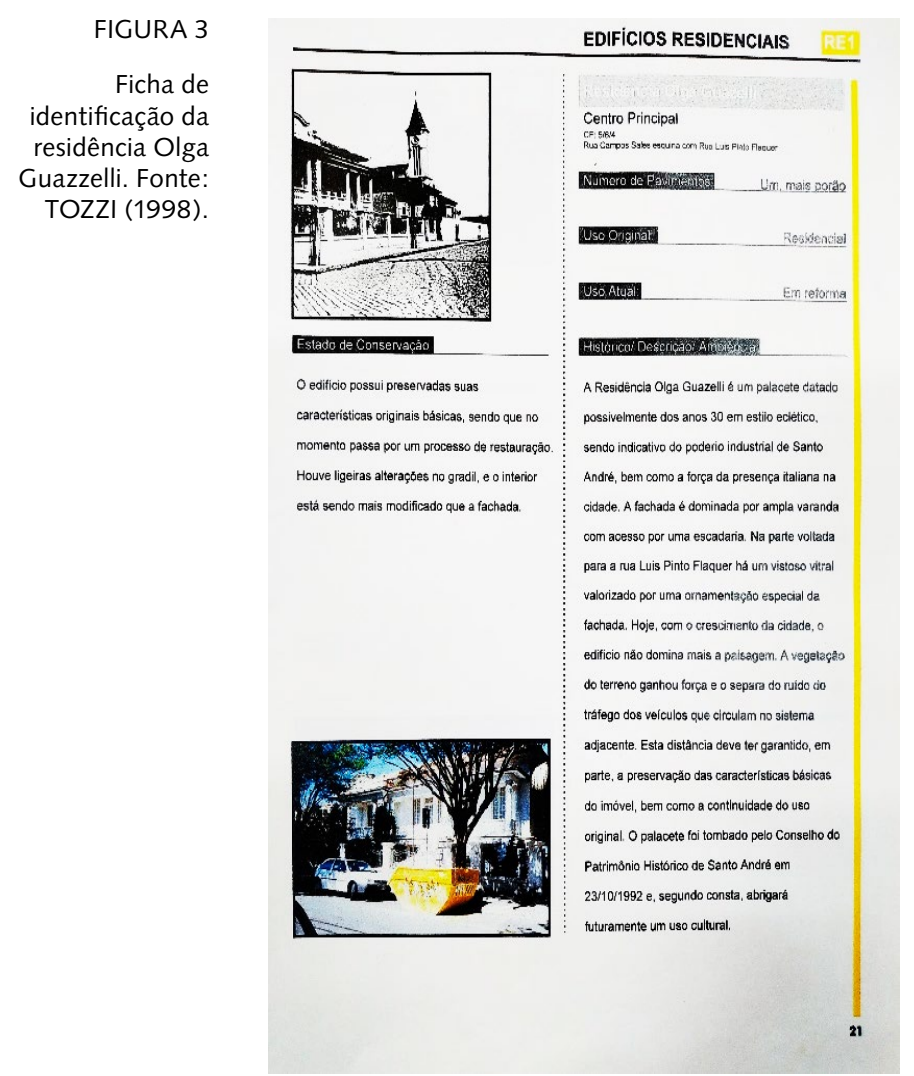

A equipe de elaboração do inventário reconheceu o caráter preliminar de suas informações, indicando a necessidade de seu aprofundamento.

3.2 Plano de preservação do patrimônio histórico e cultural do município de Santo André, 2006

Em 2006, no âmbito de revisão do Plano Diretor, a prefeitura de Santo André contratou o Laboratório de Estudos Urbanos da Metrópole (LUME), vinculado à Faculdade de Arquitetura e Urbanismo da Universidade de São Paulo, para elaboração de um plano de preservação para o município, sob a coordenação geral da arquiteta Regina Meyer e coordenação técnica da arquiteta Marta Grostein.

Integrava esse plano um inventário que abrangia a totalidade do município de Santo André e que constituiu o segundo trabalho de inventariação de patrimônio realizado no município. O plano de preservação deveria ser um instrumento para subsidiar, com informações e diretrizes, 
a elaboração das políticas públicas urbanas e de preservação em Santo André, tendo sido fundamentado no conceito de plano de preservação de sítio histórico urbano, formulado pelo Iphan (2004) e que buscava incentivar o desenvolvimento econômico associado aos valores culturais dos sítios históricos urbanos, integrando os campos do planejamento e da proteção do patrimônio.

Segundo Meyer e Grostein (2006), os bens levantados eram de interesse histórico e cultural, ligados tanto às questões históricas como à evolução urbana do município. De acordo com a equipe, a compreensão do espaço urbano levou ao reconhecimento de um passado da cidade ligado ao seu desenvolvimento industrial e, assim, foi criado o conceito de "espaços de patrimônio", de forma a articular "a preservação, a conservação e a reabilitação em uma escala de projeto urbano, que possa conciliar a memória coletiva e a cultura da cidade de herança industrial" (MEYER; GROSTEIN, 2006, p. 17).

Como metodologia, o município foi dividido em 16 espaços de patrimônio (Figura 4) na escala dos bairros: Zona Especial de Interesse Comercial (ZEIC) A - área central; Vila Assunção; ZEIP Paranapiacaba; Corredor Guarará/Vila Luzita; Parque das Nações; Parque Novo Oratório; Santa Terezinha; Vila Pires; Conjunto do IAPI; Av. Pereira Barreto; Av. Prestes Maia; Bairro Campestre/Bairro Jardim/Av. Industrial; Vila Metalúrgica; Rio Tamanduateí; Vila Euclor; e Polo Petroquímico. Os bens indicados para preservação foram levantados em listagens de bens realizadas pela prefeitura, além de estudos anteriores e visitas a campo.

$\mathrm{Na}$ área total do município foram levantados 92 bens de interesse, sendo 47 deles na área central, indicada nesse estudo como ZEIC A área central, o perímetro com o maior número de bens identificados (Figura 5).

Os dados de cada um dos bens foram sistematizados em fichas (Figura 6) com as categorias: nome; endereço; uso original; uso atual; estado de conservação; entorno; ciclo histórico; caracterização tipológica; fotos atuais; e mapas de localização em três escalas - município, perímetro do espaço de patrimônio e quadra. 

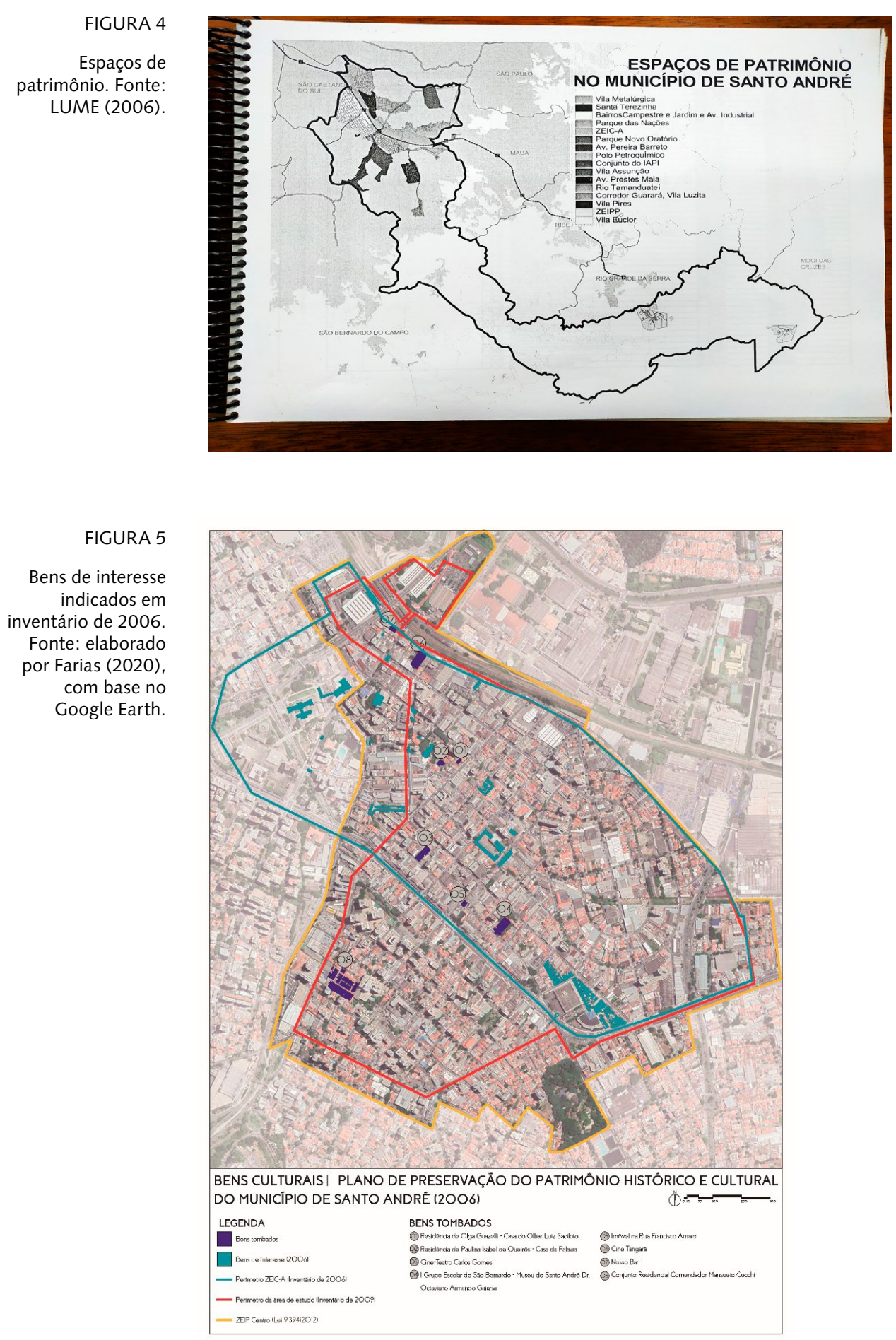


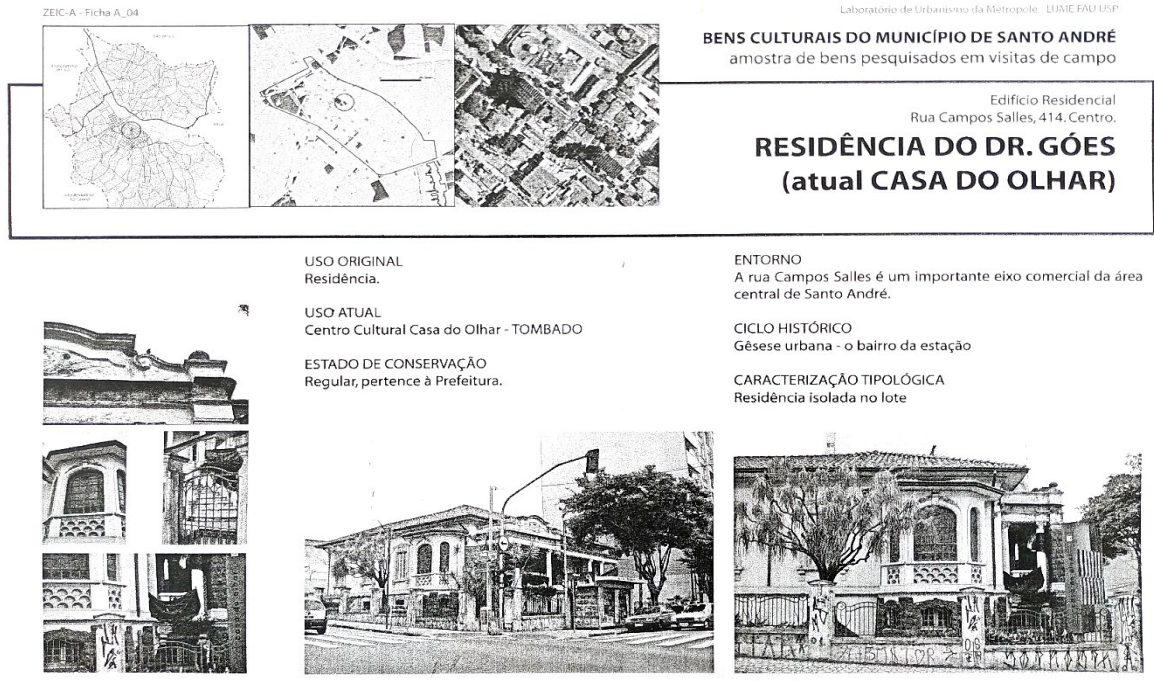

Mesmo sendo realizado para auxiliar a elaboração do Plano Diretor do município, o inventário não resultou em ações concretas de tombamento.

\subsection{Inventário de bens culturais de Santo André, 2009}

Em 2008, foi instituída a lei municipal no 9.071, de 5 de setembro, que criou o "Plano de preservação do patrimônio cultural no município de Santo André" (PPPC), que devia ser aplicado no âmbito da política municipal de preservação relacionada ao Plano Diretor do município de Santo André, aprovado em 2004. A ideia de um plano de preservação exigiu uma série de definições e condições, que gerou avanços para a política de preservação do patrimônio cultural municipal, tal como a formação de um corpo técnico estável, composto por equipe multidisciplinar, uma vez que, até aquele momento, não havia técnicos que se dedicassem exclusivamente ao Comdephaapasa.

O PPPC também determinou a elaboração de um inventário oficial de bens culturais do município, com os seguintes objetivos:

Art. 73. São objetivos do Inventário:

I. permitir a identificação dos bens culturais de interesse do patrimônio cultural, seu estado de conservação e os fatores de degradação, 
constituindo-se num processo contínuo de investigação;

II. fornecer subsídios para o encaminhamento de processos de tombamento e de registro;

III. fornecer subsídios às ações de educação patrimonial, aos programas de preservação e de salvaguarda de manifestações culturais de quaisquer naturezas;

IV. instrumentalizar as ações do Poder Público;

V. colher e armazenar dados que facilitem a identificação em casos de falsificação, roubo, comércio ilegal, descaracterização, depredação e deterioração dos bens culturais (SANTO ANDRÉ, 2008).

O corpo técnico do órgão municipal de preservação do patrimônio cultural iniciou, então, a elaboração do que seria o terceiro inventário de Santo André, o "Inventário de bens culturais de Santo André", constituindo um projeto piloto para a área central, posteriormente realizado em outras regiões da cidade. Esse estudo foi iniciado em 2008, prevendo cinco etapas de execução, sendo que sua etapa final ainda não foi concluída.

A primeira etapa foi a definição dos conceitos que seriam utilizados. O inventário foi concebido

como um instrumento de identificação, conhecimento, difusão e salvaguarda de bens e manifestações culturais que expressasse de forma plural, sistemática e permanente as ações de intervenção no espaço da cidade (GONÇALVES; LEAL; KLEEB, 2011, p. 154).

O outro conceito foi o de "paisagem cultural", adotado a partir do entendimento da equipe de que deveriam ser abordados valores materiais e imateriais, bem como as diferentes manifestações existentes nas áreas abordadas, resultantes da ação e apropriação humana sobre o território. Internacionalmente, a paisagem cultural tinha sido definida na Recomendação no 95, de 11 de setembro de 1995, da Convenção Europeia da Paisagem²:

Partes específicas, topograficamente delimitadas da paisagem, formadas por várias combinações de agenciamentos naturais e humanos, que ilustram a evolução da sociedade humana, seu estabelecimento e seu caráter através do tempo e do espaço e quanto de valores reconhecidos

2. No Brasil, o Iphan regulamentaria a chancela da paisagem cultural por meio da Portaria ${ }^{\circ}$ 127, de 30 de abril de 2009. 
têm adquirido social e culturalmente em diferentes níveis territoriais, graças à presença de remanescentes físicos que refletem o uso e as atividades desenvolvidas na terra no passado, experiências ou tradições particulares, ou representação em obras literárias ou artísticas, ou pelo fato de ali haverem ocorrido fatos históricos (CURY, 2004, p. 331).

A segunda etapa consistiu na delimitação da área de estudo. Foram realizadas pesquisas sobre os caminhos abertos no território no início de sua ocupação, como o Caminho do Pilar e o Caminho do Mar, eixos ainda hoje presentes no traçado da região, além da linha férrea São Paulo Railway, que deu origem ao núcleo urbano do final do século XIX. Assim, a área de estudo foi demarcada por esses eixos, compreendendo o que atualmente é a área central do município, o bairro Casa Branca e parte da Vila Assunção.

A terceira etapa foi o diagnóstico da área central, na qual foi realizada pesquisa de campo em que foram fotografadas as quadras do perímetro delimitado, registrando-se as edificações, os elementos da paisagem, as calçadas e as manifestações culturais e as características imateriais da área. Foram analisados documentos de fontes primárias e secundárias, identificando aspectos socioeconômicos, usos na região e a legislação incidente. Nessa etapa foi desenvolvido um levantamento iconográfico por década, a partir de 1900, com o objetivo de identificar as transformações na paisagem urbana ao longo do tempo, bem como os bens de interesse para tombamento (Figura 7).

A quarta etapa foi a divisão da área de estudo em 18 paisagens culturais (Figura 8), utilizando como critério as características predominantes em cada quadra, agrupando-as de acordo com suas semelhanças. Algumas quadras fizeram parte do que a equipe chamou de "paisagem exótica", quando suas características não se aproximavam de nenhuma outra, resultado das diversas transformações urbanas.

A quinta e última etapa compreendeu a sistematização e a análise dos dados das etapas anteriores. Para cada uma das paisagens foram definidas categorias de identificação: uso inicial; valor imaterial; estado de conservação; atividades cotidianas e festividades; elementos arquitetônicos; período provável da construção; calçadas (tipos); tampas de bueiros; entorno dos bens de interesse; sensações (sons, imagens, cheiros); e área verde urbana (Figura 9). As categorias apresentam, também, subcategorias, definidas a partir dos usos e das características das edificações. 
FIGURA 7

Bens de interesse indicados em inventário de 2009.

Fonte: elaborado por Farias (2020)

com base no

Google Earth.

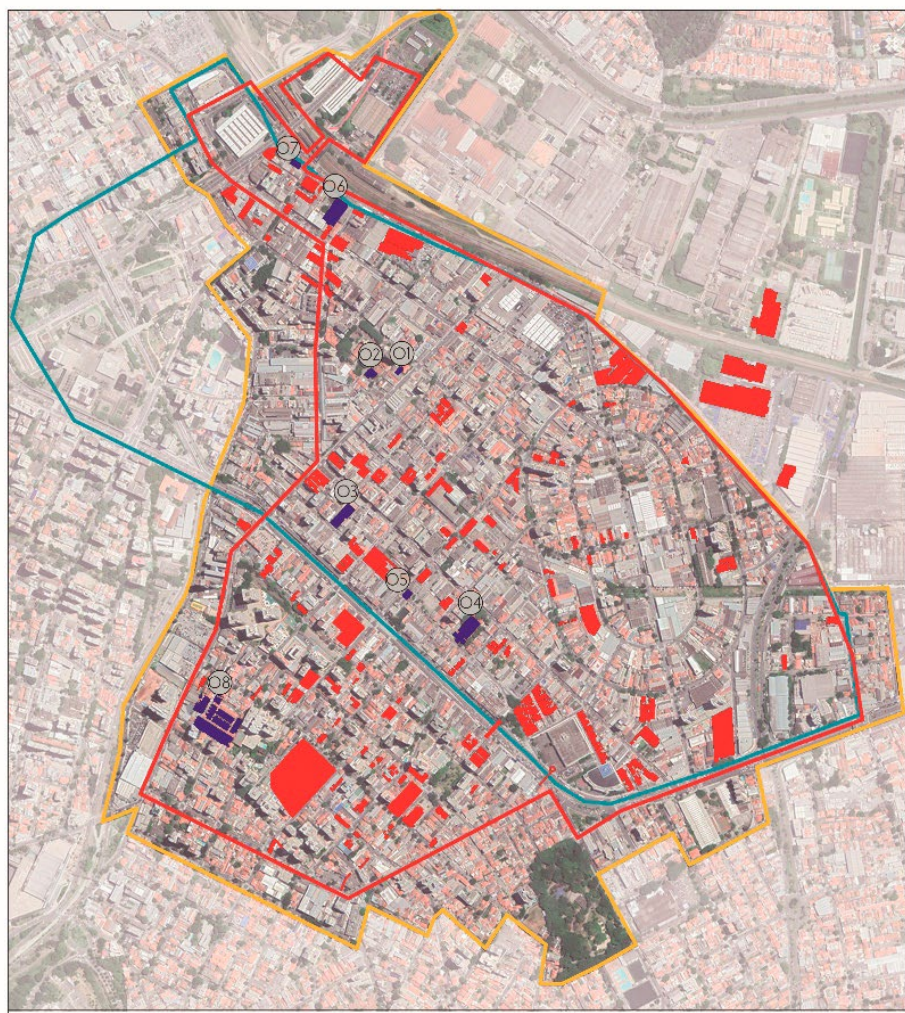

BENS CULTURAIS | INVENTĀRIO DOS BENS CULTURAIS DE SANTO ANDRĒ (2OO9)

$\longrightarrow$

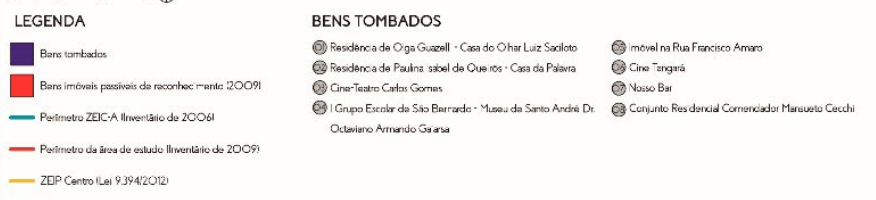

FIGURA 8

Identificação das paisagens. Fonte:

Comdephaapasa

(2009)
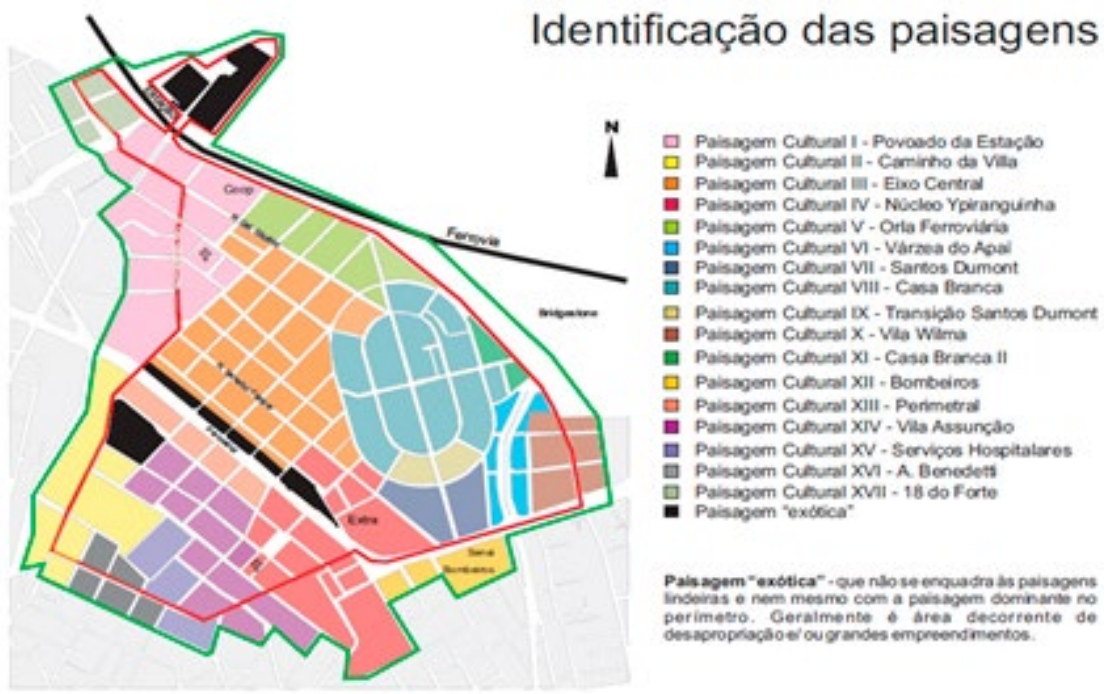
FIGURA 9

Ficha da categoria de uso inicial para a Paisagem Cultural

I, identificada como "Povoado da Estação". Fonte: Comdephaapasa (2009).

\section{Paisagem Cultural I - Povoado da Estação}

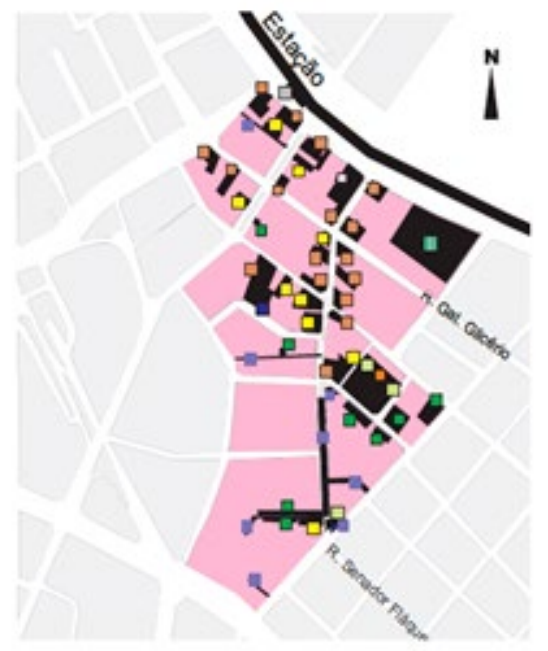

Categorias

(uso inicial)

Servipos Públicos e Instatuiç̋̄es

$\square$ Clubes e Associaģōes

Igrejas e Templos

$\square$ Praças e dreas verdes

In Edif. Industrial

口Edif, uso misto

E Edif. Residencial

E Edif. Comercial

口 Culura e Lazer

$\square$ Locais de ensino

- Ainda nåo determinado

Y: Saúde

Estrutura Urbana

II Transporte

A fase final não foi concluída, pois, durante as pesquisas, o corpo técnico sofreu alterações, e a equipe não conseguiu prosseguir com o inventário. Apesar disso, o estudo contribuiu com um resultado concreto para as políticas de preservação, tais como a adoção do perímetro de estudo do inventário como ZEIP, no âmbito do Plano Diretor do município de Santo André (Lei municipal no 9.394, de 5 de janeiro de 2012), que tem como objetivo a "proteção da paisagem cultural e de sua identidade, preservando-se a área de origem do atual município de Santo André" (SANTO ANDRÉ, 2012).

\section{VISÕES DE PATRIMÔNIO CULTURAL E CIDADE NOS TRÊS INVENTÁRIOS}

Os três inventários apresentados possibilitam uma análise comparativa com relação à visão de cidade e de patrimônio cultural revelada em cada procedimento.

O quadro síntese dos três inventários (Figura 10) mostra os distintos aspectos, conceitos e valores envolvidos nos processos de identificação do patrimônio cultural na área central de Santo André nos últimos 20 anos. 


\begin{tabular}{|c|c|c|c|c|c|}
\hline \multirow{11}{*}{$\begin{array}{r}\text { FIGURA } 10 \\
\text { Quadro síntese } \\
\text { dos três } \\
\text { inventários - } \\
\text { Área central de } \\
\text { Santo André } \\
\text { (1998, 2006, } \\
\text { 2009). Fonte: } \\
\text { elaborado por } \\
\text { Farias (2020). }\end{array}$} & \multicolumn{2}{|c|}{ INVENTÁRIO } & $\begin{array}{l}\text { Inventário dos Bens Culturais } \\
\text { de Interesse Urbanístico }\end{array}$ & $\begin{array}{c}\text { Inventário do Plano de } \\
\text { Preservação do Patrimônio } \\
\text { Histórico e Cultural - Bens } \\
\text { culturais do município } \\
\text { de Santo André }\end{array}$ & $\begin{array}{l}\text { Inventário de Bens Culturais } \\
\text { de Santo André }\end{array}$ \\
\hline & \multicolumn{2}{|c|}{ AUTOR } & $\begin{array}{l}\text { Décio Tozzi Arquitetura e } \\
\text { Urbanismo }\end{array}$ & LUME - FAU USP & $\begin{array}{l}\text { Gerência de Preservação de } \\
\text { Memória - Corpo técnico }\end{array}$ \\
\hline & \multicolumn{2}{|c|}{$\begin{array}{l}\text { ORGANIZAÇĀO } \\
\text { DO INVENTARIO } \\
\end{array}$} & $\begin{array}{l}\text { Categorias de uso/tipologia dos } \\
\text { edificios }\end{array}$ & Espaços de patrimônio & Paisagens culturais \\
\hline & \multicolumn{2}{|c|}{ ANO } & 1998 & 2006 & 2009 \\
\hline & \multicolumn{2}{|c|}{ HISTÓRICO } & Histórico/Descrição/Ambiência & Ciclo histórico & \\
\hline & \multicolumn{2}{|c|}{$\begin{array}{l}\text { CARACTERISTICAS } \\
\text { GERAIS }\end{array}$} & $\begin{array}{l}\text { Levantamento no centro e centro } \\
\text { expandido (Centro e Bairro Jardin } \\
\text { Não há visão de conjunto }\end{array}$ & $\begin{array}{l}\text { Levantamento de todo o municípid } \\
\text { Visão de conjunto dos espaços }\end{array}$ & $\begin{array}{l}\text { Area central } \\
\text { Visão fragmentada - } 18 \text { paisagens }\end{array}$ \\
\hline & \multicolumn{2}{|c|}{$\begin{array}{l}\mathrm{N}^{\circ} \text { DE BENS DE } \\
\text { INTERESSE DE } \\
\text { PRESERVACÂOO } \\
\end{array}$} & 71 & 47 & 219 \\
\hline & \multirow{2}{*}{ 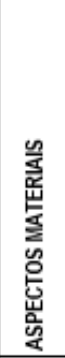 } & 은 & $\begin{array}{l}\text { Nome, endereço, imagem } \\
\text { antiga/atual } \\
\text { Número de pavimentos } \\
\text { Estado de conservação } \\
\text { Uso original } \\
\text { Uso atual }\end{array}$ & $\begin{array}{l}\text { Nome, endereço, mapa, imagem } \\
\text { Caracterização tipológica } \\
\text { Estado de conservação } \\
\text { Uso original } \\
\text { Uso atual }\end{array}$ & $\begin{array}{l}\text { Identificação dos bens de } \\
\text { interesse - conjunto no mapa } \\
\text { Elementos arquitetônicos } \\
\text { Estado de conservação } \\
\text { Uso inicial }\end{array}$ \\
\hline & & 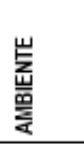 & & Entorno & $\begin{array}{l}\text { Calçadas } \\
\text { Tampas de bueiros } \\
\text { Entorno dos bens de interesse } \\
\text { Area verde urbana }\end{array}$ \\
\hline & \multicolumn{2}{|c|}{$\begin{array}{l}\text { ASPECTOS } \\
\text { IMATERIAIS }\end{array}$} & & & $\begin{array}{l}\text { Valor imaterial } \\
\text { Atividades cotidianas e } \\
\text { festividades } \\
\text { Sensações }\end{array}$ \\
\hline & \multicolumn{2}{|c|}{ RESULTADOS } & $\begin{array}{l}\text { Inserção de alguns bens no } \\
\text { projeto do Corredor Cultural } \\
(2000)\end{array}$ & Sem resultados & $\begin{array}{l}\text { Área de estudo incorporada ao } \\
\text { Plano Diretor (2012) - ZEIP }\end{array}$ \\
\hline
\end{tabular}

A identificação do patrimônio cultural no primeiro inventário, de 1998, é realizada por meio de listagens, com pouca aproximação, de fato, ao território urbano, ainda que seu foco tenha sido, justamente, como seu próprio nome designa, o "interesse urbanístico". Isso se traduz na identificação de bens isolados de seu entorno, desconsiderando-se o contexto urbano em que estão inseridos. Esse isolamento se aproxima ao tratamento dado aos monumentos, valorizados por sua materialidade, deixando em segundo plano os valores sociais e afetivos para o habitante. Essa lógica foi predominante no âmbito da preservação no Brasil até o final da década de 1980, mas, como confirma o primeiro inventário de Santo André, realizado uma década depois, tal procedimento ainda resistiu nos processos de identificação de bens culturais. 
Nas décadas de 1980 e 1990, essa visão do bem isolado, a ser apreciado pelos seus valores histórico e artístico, bem serviu ao propósito dos planos de reurbanização e revitalização de centros da época. De fato, esses planos visavam a realizar transformações nas áreas centrais de cidades que tinham perdido sua base econômica industrial e que buscavam no terciário, ou mesmo na indústria do entretenimento e do turismo, sua nova base produtiva. Para tanto, utilizavam-se de estratégias conhecidas como city marketing que, segundo Vargas (2001, p. 8), são formas de "vencer a competição entre lugares, buscando identificar as vocações reais dos municípios, suas dificuldades e oportunidades, diante dum determinado cenário".

Nesse sentido, o bem patrimonial é visto como um produto cultural que deve alimentar a nova condição urbana. Com efeito, de acordo com Choay (2017, p. 211):

Os monumentos e o patrimônio histórico adquirem dupla função obras que propiciam saber e prazer, postas à disposição de todos; mas também produtos culturais, fabricados, empacotados e distribuídos para serem consumidos. A metamorfose de seu valor de uso em valor econômico ocorre graças à "engenharia cultural", vasto empreendimento público e privado, a serviço do qual trabalham grande número de animadores culturais, profissionais da comunicação, agentes de desenvolvimento, engenheiros, mediadores culturais. Sua tarefa consiste em explorar os monumentos por todos os meios, a fim de multiplicar indefinidamente o número de visitantes.

A imagem da cidade a ser vendida no contexto que se estruturava, devido à desindustrialização, deveria estar associada a boa qualidade de vida, infraestrutura adequada e serviços urbanos de qualidade a fim de não prejudicar sua competitividade com outros municípios. Dentre esses aspectos, também se considerava o campo da cultura:

No entanto, o eixo estruturante da competitividade exige também um equacionamento dos constrangimentos relacionados com o entorno social, cultural e estético do próprio espaço urbano, pois, esses fatores influenciam diretamente a qualidade de vida e a atratividade do espaço para os agentes econômicos externos. A cidade competitiva deveria mostrar, portanto, um grau de pobreza, marginalização e violência tolerável para não perder a atividade. Deveria também oferecer uma gama ampla de serviços culturais e urbanísticos para influenciar positivamente as decisões locacionais das empresas (KLINK, 2001, p. 33). 
É nesse contexto que se insere o primeiro inventário, preocupado em identificar bens culturais com base em valores históricos e estéticos, como pontos de interesse de um circuito - o Corredor Cultural - que deveria valorizar o centro da cidade.

Ainda, a seu favor, é importante destacar a relação desse inventário com um projeto associado à política urbana municipal, valorizando a dimensão urbana do patrimônio cultural.

Desse primeiro inventário resultou a inserção de alguns bens nele identificados no circuito do Corredor Cultural, abertos à visitação pública. Hoje, embora esse Corredor ainda exista e nele sejam realizadas algumas ações, tais como exposições e piqueniques no Museu de Santo André Dr. Octaviano Armando Gaiarsa, essas atividades ainda não alcançam um número significativo de visitantes ou pouco dialogam com as práticas sociais ocorridas nesses lugares.

Já o segundo inventário, de 2006, insere-se em um contexto de busca de integração com o planejamento urbano, uma vez que foi criado no momento de revisão do Plano Diretor do município de Santo André, em uma tentativa de relacionar as questões de planejamento e de preservação. Diga-se que essa iniciativa é incentivada, já em 1975, na Declaração de Amsterdã, elaborada durante o Congresso do Patrimônio Arquitetônico Europeu, que coloca a conservação integrada como essencial à cidade:

\footnotetext{
O planejamento das áreas urbanas e o planejamento físico territorial devem acolher as exigências da conservação do patrimônio arquitetônico e não considerá-las de uma maneira parcial ou como um elemento secundário, como foi o caso num passado recente. Um diálogo permanente entre os conservadores e os planejadores tornou-se, desde então, indispensável (IPHAN, 2004).
}

Dessa forma, a noção de patrimônio cultural, nesse inventário, fundamentou-se na definição dos chamados "espaços de patrimônio", considerando-se a sua inserção na dinâmica urbana - uma dinâmica essencialmente comercial, como se verifica no inventário, na identificação do centro como ZEIC. Por outro lado, a argumentação do inventário reconhece Santo André como uma cidade industrial, com a indicação de vilas operárias, fábricas e indústrias que fizeram parte do seu passado industrial, sendo que alguns desses exemplares ainda estão presentes nesse território. 
Verifica-se, ainda, que as fichas de identificação dos bens apresentam categorias que reconhecem, essencialmente, os valores materiais. Uma das categorias indicadas é a de "ciclos históricos", que pode ser comparada à proposta de "ciclos econômicos" adotada pelo Condephaat, na década de 1970, para a identificação de bens patrimoniais no estado de São Paulo. Segundo Rodrigues (1999, p. 44), a noção de ciclos compreende a

ideia de progresso, decadência, e sucessão contínua de atividades exclusivas [...] o ciclo afigurava-se como forma de situar um bem material nos limites do tempo e do espaço dando-lhe historicidade, embora restrita, pois o critério econômico não atende à complexa rede de relações culturais presentes em um período histórico.

Como se constata, a definição de ciclos históricos ou econômicos não abarca as diversas camadas que conformam a cidade, restringindo o patrimônio cultural a determinado grupo ou período.

As fichas apresentam, ainda, uma identificação superficial dos bens, que apesar de estarem inseridos em mapas que contextualizam o patrimônio dentro do espaço urbano, não indicam categorias que os relacionem à cidade ou reconheçam os seus valores imateriais.

Finalmente, o terceiro inventário, realizado pelos técnicos do Comdephaapasa e ainda não concluído, utiliza um conceito recente dentro do campo do patrimônio, que é o da "paisagem cultural".

O patrimônio cultural, nesse inventário, foi reconhecido tanto por seus valores materiais quanto imateriais, compreendendo as complexas e variadas relações do habitante com a cidade. Essas relações se manifestam nas categorias apresentadas no inventário quando esse explora, por exemplo, o reconhecimento dos cheiros e das sensações - o que evoca questões subjetivas atinentes aos bens culturais.

A categoria "atividades cotidianas e festividades" diferencia-se daquelas comumente contempladas nos inventários, pois desloca o interesse dos bens materiais para os sujeitos e suas manifestações no território. De acordo com Meneses (2017, p. 50), é importante,

para respeitar a natureza social do patrimônio ambiental urbano, transferir o excessivo e por vezes exclusivo foco de interesse nos bens (materiais ou imateriais), e no poder público, para os sujeitos - os agentes humanos, nas suas multiformes interações. 
O reconhecimento da área central do município de Santo André como uma paisagem cultural é inovadora. Contudo, o inventário fragmenta de forma excessiva o território estudado, identificando 18 paisagens distintas apenas na área central da cidade. É possível observar na Figura 8 que foram definidas paisagens que abarcam apenas duas quadras, o que dificulta a compreensão do perímetro de estudo como um todo.

A divisão em várias paisagens também proporciona outro desafio: a gestão da área. A chancela da paisagem cultural, proposta pelo Iphan, como instrumento de proteção e manutenção de uma área urbana, procura promover a gestão integrada, conciliando preservação e planejamento. Isso se reflete no próprio Plano Diretor do município, que incorporou o perímetro de estudo como uma única e importante área a ser preservada (ZEIP - área central).

Assim, a partir da análise dos três inventários é possível sintetizar algumas considerações a respeito do patrimônio cultural em Santo André.

Em curto espaço de tempo - uma década - verificaram-se diferentes formas de conceituação do patrimônio cultural ao longo das experiências de inventariação. Como se viu, o primeiro inventário, de 1998, fundamentou-se na ideia de patrimônio como bem isolado do seu entorno; o segundo, de 2006, definiu "espaços de patrimônio" com base na categoria analítica dos "ciclos históricos", que tende a valorizar determinados grupos sociais em detrimento de outros; o terceiro, de 2009, apresentou o conceito de "paisagem cultural", que se distingue das concepções anteriores por contemplar, também, os valores imateriais do patrimônio. Dessa forma, a identificação do patrimônio cultural implica não só reconhecer sua materialidade, mas também sua imaterialidade, revelando, assim, sua importância social. A memória, importante na relação do ser humano com o ambiente em que vive, é um aspecto que deve fazer parte do processo de reconhecimento dos valores do patrimônio cultural:

Observamos que a memória se traduz em um poder simbólico que confere a grupos sociais sentido de permanência e de unidade no tempo e colabora para a construção de identidades. A identidade ou as identidades vinculam-se a aspectos que conferem reconhecimento e "pertencimento" de um grupo a certo espaço. Depreende-se, então, que a memória agrega-se a um determinado lugar, enquanto espaço da produção humana e de apropriação da vida (KLEEB, 2013, p. 36). 
Além disso, verifica-se, nos dois últimos inventários, a busca de uma relação integrada entre os campos da preservação e do planejamento: o de 2006 identifica e divide o território a partir dos "espaços de patrimônio", e o inventário de 2009 lê o território como um conjunto de paisagens culturais - procedimento que resultou na formalização, na área central da cidade, de uma zona de preservação do patrimônio.

A dimensão urbana do patrimônio defendida por Gustavo Giovannoni, na década de 1930, e também na Carta de Veneza, de 1964, bem como a chamada "conservação integrada" da Declaração de Amsterdã, de 1975, chamaram a atenção tanto para a relação entre o patrimônio e o ambiente urbano quanto para a necessária vinculação entre preservação e planejamento. O inventário elaborado pelo LUME, em 2006, coloca, explicitamente, essa questão, ao abordar a gestão dos espaços de patrimônio no âmbito das políticas urbanas. De modo semelhante, o inventário realizado em 2009, pela equipe técnica municipal, também é uma clara tentativa de integrar o campo da preservação ao do planejamento, a partir do reconhecimento do território como paisagem e da adoção de seu perímetro de estudo pelo planejamento urbano, na regulamentação da ZEIP.

Ressalte-se que nos três inventários verificou-se a ausência ou uma escassa participação social - procedimento que passou a ser considerado de extrema importância para as políticas de reconhecimento do patrimônio cultural. A desejável inserção do patrimônio na dinâmica urbana e na vida cotidiana das pessoas, que deve ser construída, portanto, com a contribuição da participação social, torna a preservação uma ação efetiva, ao expressar, assim, a memória e a identidade de diferentes grupos sociais e culturais.

Já a visão de cidade que se tem em cada um dos três inventários é divergente. Enquanto a primeira, a do inventário de 1998, relaciona-se com a ideia de cidade que busca na valorização do centro o seu diferencial na competição com outras urbes, a segunda, a do inventário de 2006, é aquela da cidade definida por suas distintas camadas no tempo, em que a evolução urbana e a tipologia arquitetônica encontram suas correspondências na categoria de "espaços de patrimônio". Já a terceira perspectiva se aproxima da ideia de cidade como bem cultural e que deve ser compreendida a partir das práticas sociais que ali têm lugar. Essa ideia é defendida por Meneses desde a década de 1970 e se fundamenta em três noções: a cidade como 
artefato; como campo de disputas; e como representação social, categoria de aproximação ao patrimônio muito pouco utilizada até recentemente.

Assim, pode-se dizer que a cidade da história vai cedendo lugar à cidade da memória, ainda que, para tanto, seja necessário que os sujeitos sociais nela se reconheçam, fazendo parte, assim, do processo de identificação do que consideram seu patrimônio cultural.

Com efeito, depois da Segunda Grande Guerra, iniciam-se debates, no campo da arquitetura e do urbanismo, sobre os valores do ambiente, do habitat e da memória na construção da cidade - uma perspectiva absolutamente crítica à ausência dessas questões na produção das chamadas "vanguardas modernas" até a segunda metade do século XX. Nessa nova percepção, adquire maior relevância a relação dos objetos entre si do que sua importância intrínseca - visão que havia predominado, até então, no movimento moderno em arquitetura e urbanismo.

No entanto, se nos últimos 20 anos a cidade libertou-se dessas amarras do moderno, ficando livre para alimentar-se nas fontes da memória, a globalização a lançou em uma disputa entre centros de concentração de fluxos, sejam eles econômicos, sociais, políticos ou culturais: quanto mais fluxos, melhor. Não à toa, o patrimônio deve entrar no circuito da competição entre cidades, potencializando novas centralidades.

Nesse panorama, Santo André, a partir da década de 1990, também não escapa desse circuito, como resposta à perda de sua vitalidade industrial. E, nessa direção, tanto a cidade do primeiro inventário como a do segundo não fugiram a essa lógica. No caso do primeiro inventário, sua concepção, associada a projeto de atração urbana, concentrou a seleção dos bens culturais a serviço de uma proposta que, independentemente de sua qualidade, conduz à redução de uma potencial diversidade do patrimônio local.

Em relação ao segundo inventário, as análises morfológicas e tipológicas remetem a procedimentos de leitura da cidade mais contemporâneos, no sentido de se buscar entender a sua construção no tempo, e fundamentaram um processo de escolha de bens mais articulado do que a seleção de bens isolados, como no caso do primeiro inventário. Além disso, a proposta metodológica inspirava-se na política federal do Iphan, que buscava, naquele momento, a dinamização econômica de sítios históricos urbanos. 
Já a cidade do terceiro inventário é constituída por um mosaico de partes com características específicas e valores intangíveis que não se pode compreender apenas por meio da seleção de bens materiais. Seu reconhecimento, portanto, exige um conceito mais amplo dos elementos que conformam o território, que é o da paisagem cultural. A simples proteção pelo tombamento, nesse caso, é insuficiente. Fragmentada, essa cidade é de difícil apreensão em seu conjunto, embora esteja mais próxima de uma desejável diversidade do patrimônio.

\section{CONSIDERAÇÕES FINAIS}

O inventário, importante instrumento de identificação do patrimônio cultural, também pode contribuir para o enriquecimento do debate sobre o urbano, ao destacar elementos materiais e imateriais conformadores da cidade, que permanecem e se transformam no tempo e no espaço, sendo, no caso do patrimônio material, suporte físico para as referências culturais dos habitantes. Pode, ainda, fornecer subsídios multidisciplinares que auxiliem futuras intervenções e a implementação de políticas urbanas que contemplem as várias dimensões da cidade, articulando os campos da preservação e do planejamento urbano.

No caso concreto de Santo André, três inventários foram realizados em apenas 11 anos, um espaço de tempo curto quando comparado a experiências de outros municípios. Como exposto neste artigo, a análise das três experiências distintas - tanto em relação aos seus conceitos quanto à metodologia utilizada - demonstra as mudanças da noção de patrimônio cultural a partir das visões de história, espaço e memória evidenciadas, ou subjacentes, em cada estudo. Com efeito, o conceito de bem isolado, ao longo de uma década, cedeu espaço para a paisagem cultural, com o reconhecimento da imaterialidade, das práticas sociais e da necessidade da gestão integrada.

Os inventários, entretanto, não resultaram, ainda, em proteção concreta dos bens indicados por meio de tombamento ou outro instrumento de reconhecimento, como o registro ou a chancela. Esse fato pode ser explicado pela falta de relação entre os estudos - cada um deles realizado por distintas equipes e a partir de diferentes enfoques -, reflexo, também, da descontinuidade das gestões administrativas do município, que não concluíram os projetos das gestões anteriores. A única medida concreta de proteção foi 
alcançada, como fruto do terceiro inventário, por meio da adoção de um perímetro de preservação do patrimônio pelo Plano Diretor do município de Santo André - a ZEIP aqui estudada. Contudo, mesmo nesse caso, o perímetro não apresenta diretrizes de intervenção claramente definidas, dificultando a manutenção da ambiência da área que se procurou proteger. Além dessas constatações, esse contexto de preservação do patrimônio cultural em Santo André identificou alguns desafios:

- a necessidade de construção de instrumento de inventariação que considere a visão dos diversos grupos sociais que constituem a cidade, ou seja, que inclua as percepções dos habitantes e suas representações urbanas, como defende Meneses (2017);

- o fortalecimento da prática de articulação do inventário com políticas de planejamento, tornando-o um instrumento multidisciplinar que auxilie na construção da cidade e, portanto, na formulação de políticas que relacionem preservação e planejamento;

- a chancela da paisagem cultural - instrumento instituído pelo Iphan em 2009 - como prática de preservação do patrimônio; e

- o reconhecimento do passado industrial do município, visto que, dos oito bens tombados no perímetro de estudo, apenas um é característico do período industrial: o conjunto residencial Comendador Mansueto Cecchi, da década de 1950.

Finalmente, o estudo do caso de Santo André evidencia como o instrumento de inventário reflete as múltiplas visões de patrimônio cultural e de cidade, sendo imprescindível, portanto, que seja o mais abrangente, amplo e sistemático possível: abrangente em relação aos grupos sociais contemplados, amplo em seus vínculos com as políticas urbanas e sistemático no que se refere à sua continuidade no tempo.

\section{REFERÊNCIAS}

ARMELINI, Ângela I. M. da S. Q. A preservação do patrimônio em Santo André: uma avaliação sobre a contribuição do uso cultural em imóveis tombados. 2008. 216 f. Dissertação (Mestrado em História e Fundamentos da Arquitetura e do Urbanismo) - Faculdade de Arquitetura e Urbanismo, Universidade de São Paulo, São Paulo. 
CONSELHO MUNICIPAL DE DEFESA DO PATRIMÔNIO HISTÓRICO, ARTÍSTICO, ARQUITETÔNICO-URBANÍSTICO E PAISAGÍSTICO DE SANTO ANDRÉ. Inventário de bens culturais de Santo André. Santo André: Comdephaapasa, 2009.

CURY, Isabelle (org.). Cartas patrimoniais. 3 ed. rev. e aum. Rio de Janeiro: Iphan, 2004. 408 p. (Edições do Patrimônio).

FARIAS, Larissa Tesubake de. Cidade e preservação: a dimensão urbana do patrimônio cultural em Santo André. 2020. Dissertação (Mestrado em Arquitetura e Urbanismo) - Faculdade de Arquitetura e Urbanismo, Universidade São Judas Tadeu, São Paulo.

GOLLO, Reynaldo. Centro de Sto. André será revitalizado. Diário do Grande ABC, Santo André, 1 nov. 1997, s/p.

GONÇALVES, Aguinaldo; LEAL, Fátima R. T.; KLEEB, Suzana C. Reconhecimento de paisagens culturais em Santo André, SP, Brasil: uma experiência de inventário de bens culturais. Revista CPC, São Paulo, n. 12, p. 151-166, maio/out. 2011.. Disponível em: https://www.revistas. usp.br/cpc/article/view/15685. Acesso em: 23 fev. 2018.

INSTITUTO BRASILEIRO DE GEOGRAFIA E ESTATÍSTICA. Santo André. 2019. Disponível em: https://www.ibge.gov.br/cidades-e-estados/sp/santo-andre.html. Acesso em: 17 jun. 2020.

INSTITUTO DO PATRIMÔNIO HISTÓRICO E ARTÍSTICO NACIONAL. Cria o Plano de Preservação de Sítio Histórico Urbano - PPSH. Portaria n 299, de 6 de julho de 2004. Disponível em: http://portal.iphan.gov.br/uploads/legislacao/Portaria_n_299_de_6_de_Julho_ de_2004.pdf. Acesso em: 10 jun. 2020.

KLEEB, Suzana Cecília. Breve histórico de Santo André. Santo André: PMSA, 2002. 7 p.

KLEEB, Suzana Cecília. Transformações da paisagem na área central de Santo André/SP, 1911-2011. 2013. 284 f. Dissertação (Mestrado em Planejamento e Gestão do Território) Universidade Federal do Grande ABC, Santo André.

KLINK, Jeroen Johannes. A cidade-região: regionalismo e reestruturação no Grande ABC Paulista. Rio de Janeiro: DP\&A, 2001.

LANGENBUCH, Juergen Richard. A estruturação da Grande São Paulo: estudo de geografia urbana. Rio de Janeiro: IBGE, 1971.

MÉDICI, Ademir. Inventário histórico - 5: urgência em Santo André na preservação dos bens. Diário do Grande ABC, Santo André, 29 mar. 1987, B, 10.

MENESES, Ulpiano Toledo Bezerra de. Repovoar o patrimônio ambiental urbano. Revista do Patrimônio Histórico e Artístico Nacional, Brasília, DF, n. 36, p. 39-51, 2017.

MEYER, Regina M. P; GROSTEIN, Marta D. (coord.). Plano de preservação do patrimônio histórico e cultural do município de Santo André em complementação ao seu Plano Diretor. Laboratório de Urbanismo da Metrópole - LUME FAU-USP, 2006. vols. I e II.

PASSARELLI, Silvia. H. F. Proteção da paisagem ferroviária: memória e identidade do bairro estação São Bernardo (atual Santo André). 2005. 193 f. Tese (Doutorado em Estruturas Ambientais Urbanas) - Faculdade de Arquitetura e Urbanismo, Universidade de São Paulo, São Paulo. 
PINHO, Rodrigo Altair. Santo André: (Re) ordenação sócio espacial e implicações do período técnico-científico-informacional a partir dos anos 90. 2007. $240 \mathrm{f}$. Dissertação (Mestrado em Geografia Humana) - Departamento de Geografia, Faculdade de Filosofia, Letras e Ciências Humanas, Universidade de São Paulo, São Paulo.

RODRIGUES, Marly. Imagens do passado: a instituição do patrimônio em São Paulo, 1969-1987. São Paulo: Unesp/Imprensa Oficial do Estado/Condephaat/Fapesp, 1999.

SALES, Maria Angélica. Calçadão coberto abre Projeto Centro. Diário do Grande ABC, 15 mar. 1998.

SANTO ANDRÉ. Lei no 9.071, de 5 de setembro de 2008. Institui o Plano de Preservação do Patrimônio Cultural no Município de Santo André - PPPC. Santo André: Câmara Municipal, 2008. Disponível em: https://www2.santoandre.sp.gov.br/index.php/legislacao-comdephaapasa/file/586-lei-n-9-071-05-de-setembro-de-2008. Acesso em: 14 jun. 2019.

SANTO ANDRÉ. Lei no 9.394, de 5 de janeiro de 2012. Altera a Lei no 8.696, de 17 de dezembro de 2004, que instituiu o Plano Diretor no Município de Santo André, atendendo o art. 181 que prevê a revisão do Plano Diretor. Santo André: Câmara Municipal, 2012. Disponível em: https:// consulta.siscam.com.br/camarasantoandre/arquivo?Id=37630. Acesso em: 17 jun. 2020.

TAKARA, Jaqueline da Silva. O Centro Popular de Cultura de Santo André e sua proposta de um teatro proletário. Revista Aspas, São Paulo, v. 8, n. 2, p. 154-165, 2018.

TOZZI, Décio (coord.). Inventário de interesse urbanístico do centro principal e expandido do município de Santo André. Relatório dos resultados da pesquisa de uso e ocupação do solo da área central. Santo André: S.C.P., 1998, Anexo 1.

VARGAS, Heliana Comin. Gestão de áreas urbanas centrais: a experiência de Santo André. Artigo encaminhado para o IX ENCONTRO NACIONAL DA ANPUR. Rio de Janeiro, maio de 2001. Não publicado.

\section{(cc) $\mathrm{EY}-\mathrm{Mo}-\mathrm{BA}$}

